Edward Walewander

Lublin

\title{
POLSCY STUDENCI TEOLOGII W INNSBRUCKU PO DRUGIEJ WOJNIE ŚWIATOWEJ
}

\section{Początki i rozwój studiów Polaków zagranicą}

Już w średniowieczu Polacy - zwłaszcza osoby duchowne - zaczęli wyjeżdżać zagranicę $\mathrm{w}$ celu dalszego kształcenia się, jednak dopiero w okresie odrodzenia i reformacji nastąpiło upowszechnienie podróży w ogóle, zaś peregrynacji naukowych w szczególności. Chęć poznawania obcych krajów, a zwłaszcza zdobywania wiedzy w najlepszych ośrodkach ogarnęła prawie całą Europę. Zagranicą studiowała młodzież angielska, duńska, niemiecka, szwedzka.

Zamiłowanie do wojaży zagranicznych nie ominęło także Polaków. Były one na tyle powszechne, że zjawisko to można uznać za masowe. Pęd ten rozwijał się wśród szlachty od lat czterdziestych XVI stulecia, a w drugiej jego połowie osiągnął punkt kulminacyjny. Z pewnością sprzyjał temu wzrost zamożności szlachty oraz jej dominacja w społeczno-politycznym życiu państwa.

Na przełomie XV i XVI w. hegemoniczne dążenia szlachty doprowadziły do postanowień prawnych, zgodnie z którymi szlachcic mógł objąć najwyższe stanowiska duchowne czy świeckie bez potrzeby legitymowania sięjakimkolwiek cenzusem naukowym. Plebejuszowi natomiast dopiero naukowy dyplom uniwersytecki otwierał drzwi do ewentualnej dalszej kariery - najlepiej jeśli ukończył jakąś prestiżową uczelnię zagraniczną ${ }^{1}$. Takim wymaganiom nie mógł odpowiadać przestarzały i oderwany

${ }^{1}$ Por. Radomiensis Conventionis Decreta Aleksandri Regis [Konstytucje wieczyste Sejmu Radomskiego 1505 roku], oprac. W. Uruszczak, W.T. Kacperski, E. Orzechowska, Radom 2005, p. 12 i 13. Znany pamiętnikarz Jan Duklan Ochocki wspominał, że książę Karol Radziwiłł (1734-1790) miał zwyczaj „synów obywateli lub swoich klientów - a kto w Litwie nie był 
od problemów życia program naukowy realizowany w konserwatywnej Akademii Krakowskiej. Poszukiwanie nowoczesnych możliwości zdobywania potrzebnego wykształcenia doprowadziło do wyjazdów zagranicę na dużą skalę.

\section{Innsbruck jako miejsce edukacji}

Jednym z ważnych ośrodków zagranicznych, do którego polska młodzież udawała się na studia, był Innsbruck. Miasto to było dobrze znane podróżnikom z Polski, którzy jechali tędy głównie do Monachium², do Włoch ${ }^{3}$ lub do innych krajów Europy Zachodniej ${ }^{4}$.

Szukających rzetelnej wiedzy do miasta nad Innem ściągało istniejące tam od 1561 r. kolegium jezuickie. Jego poziom naukowy musiał być wysoki, skoro z czasem dał podstawę do erygowania w 1669 r. uniwersytetu (w 1677 r. otrzymał potwierdzenie papieskie), początkowo tylko z wydziałem filozoficznym. Wkrótce, bo już w 1671 r., utworzono wydział teologii i prawa, a trzy lata później - wydział medyczny. Po kasacie zakonu jezuitów w 1773 r. uniwersytet przechodził różne koleje. Był nawet zdegradowany do stopnia liceum. W 1826 r. cesarz Franciszek II przywrócił uczelni rangę uniwersytetu $\mathrm{z}$ wydziałami prawa i filozofii. W $1857 \mathrm{r}$. reaktywowano wydział teologii. Powierzono go jezuitom ${ }^{5}$. Kierują oni tym wydziałem do dzisiaj. W 1858 r. w Innsbrucku został otwarty konwikt teologiczny. Wkrótce - na jego bazie - powstało międzynarodowe Collegium Canisianum, prowadzone przez austriacką prowincję jezuitów ${ }^{6}$. W roku akademickim 2012/13 uniwersytet posiada 16 wydziałów, na których studiuje ponad 27 tys. studentów.

klientem Radziwiłłowskim? - szlacheckie dzieci, a nawet ludzi innych stanów, gdy się w nich tylko talent odkrył, wysyłać za granice dla ukształcenia i usposobienia. Było takich niemało, którzy kosztem jego wysłani, byli później użytecznymi dla kraju obywatelami". Tenże, Pamiętniki, Warszawa, bm i rw, t. II, s. 43.

2 Por. E. Czapski, Pamiętniki sybiraka, red. M. Czapska, Londyn 1964, s. 115.

${ }_{3}^{3}$ Jasia Ługowskiego podróże do szkót w cudzych krajach 1639-1643, oprac. i wstęp K. Myszyńska, Warszawa 1974.

4 Por. S. Stempowski, Pamiętniki (1870-1914), wstęp M. Dąbrowska, Wrocław 1955, S. 269.

${ }^{5}$ R. Feulner, Der Priestergebetsverein im Theologischen Konvikt Collegium Canisianum zu Innsbruck, "Korrespondenzblatt des Canisianums” 1994, z. 2, s. 13-21; P. Riesterer, Erinnerung an bewegte Zeiten, ibidem, 1992, z. 2, s. 4.

"Por. Piotr Kanizjusz w Polsce, "Przegląd Kościelny” 18 VIII 1881; E. Walewander, Innsbruck, w: Encyklopedia katolicka, t. 7, Lublin 1977, kol. 260. 


\section{Polacy w Innsbrucku do drugiej wojny światowej}

Jednym z pierwszych Polaków pobierających nauki w Innsbrucku był szlachcic z ziemi łukowskiej, Jan Ługowski, który prawie cały rok 1641 był uczniem tamtejszego kolegium jezuickiego ${ }^{7}$. Doskonale zorganizowane szkolnictwo jezuickie cieszyło się sławą i dużą popularnością. Realizowany $\mathrm{w}$ nim program nauki, oparty na wypracowanym pod koniec XVI w. ratio studiorum, miał charakter całkowicie uniwersalny, jednakowy dla wszystkich krajów ${ }^{8}$.

Liczba Polaków studiujących w Innsbrucku z czasem się zwiększała. W okresie zaborów stolicę Tyrolu jako miejsce studiów wybierali przeważnie duchowni z zaboru austriackiego ${ }^{9}$. Absolwentem innsbruckiej Alma Mater był m.in. kard. Adam Sapieha z Krakowa. Najmniej było studentów z terenu zaboru rosyjskiego. Błogosławiony biskup Jerzy Matulewicz (1871-1927) zapisał w swoim Dzienniczku duchownym, że "rząd rosyjski nie cierpi Innsbrucka"10.

W okresie międzywojennym Innsbruck wybierali księża prawie ze wszystkich diecezji odrodzonej Polski. Absolwentami tamtejszej uczelni byli m.in.: Josyf Slipyj - późniejszy arcybiskup lwowski obrządku greckokatolickiego; biskup gdański Edward O’Rourke; ks. Józef Pastuszka, po drugiej wojnie światowej profesor psychologii na Katolickim Uniwersytecie Lubelskim ${ }^{11}$.

7 Jasia Ługowskiego podróże do szkót w cudzych krajach 1639-1643, oprac. i wstęp K. Myszyńska, Warszawa 1974, s. 379-385.

8 Por. Ratio atque institutio studiorum SJ czyli Ustawa Szkolna Towarzystwa Jezusowego (1599), wstęp i oprac. K. Bartnicka i T. Bieńkowski, Warszawa 2000, passim.

9 Zob. A. Karbowiak, Młodzież polska akademicka za granica 1795-1910, Kraków 1910, s. 141; E. Bojanowski, Dziennik 1853-1871, red. A. i T. Szafrańscy, Warszawa 1999, s. 233; P. Mańkowski, Pamiętniki, wstęp S. Górzyński, Warszawa 2002, s. 196. O atmosferze studiów w Innsbrucku w drugiej połowie XIX w. informowały na łamach prasy polskiej bardzo ciekawe korespondencje: Z Innsbrucka, "Przegląd Katolicki” z 11 V 1882 oraz ibidem z 18 V 1882; Z życia kościelnego w Austrii, "Przegląd Katolicki” z 11 V 1888; A.M., Andrzej Hofer, „Oświata. Tygodnik Katolicko-Narodowy dla Stanu Średniego” 24 I 1879; ibidem, 31 I 1879; Studya teologiczne w Austrii, „Przegląd Kościelny”, maj 1896, s. 334-342. Zob. także. W. Jabłonowski, Pamiętniki z lat 1851-1893, red. J. Fijałek, Wrocław 1967, s. 24; W. Ćwik, Polacy w Innsbrucku do 1939 r., w: Polonia i przyjaciele Polski w Austrii, red. W. Kucharski, Lublin 1995, s. 63-73.

10 Warszawa 1988, s. 132. Por. też: Diecezje polskie, „Przegląd Kościelny” 25 XII 1879; A. Katilius, Litwini - wychowankowie sejneńskiego Seminarium Duchownego na uniwersytetach katolickich Europy Zachodniej, w: Przeszłość natchnieniem dla teraźniejszości, red. K. Brzostek, Ełk 1996, s. 303-313, M. Jałowiecki, Na skraku Imperium i inne wspomnienia, red. M. Zwoliński, Warszawa 2012, s, 139.

11 Więcej na ten temat: W. Ćwik, Studenci i uczeni z ziem polskich na uniwersytecie w Innsbrucku do II wojny światowej, w: Polacy na uniwersytecie w Innsbrucku, s. 17-73. 
Znaczna liczba Polaków na studiach w Austrii w latach 1918-1939 była znakomitą odpowiedzią na wskazówki Bolesława Prusa, który na początku XX stulecia na łamach „Tygodnika Ilustrowanego" pisał: „Nasz naród, bardzo zacofany, koniecznie potrzebuje, ażeby nie dziesiątki i setki, ale tysiące jego młodzieży wyjeżdżało za granicę nie tylko w celu zdobycia naprawdę wiedzy uniwersyteckiej czy technicznej, ale i poznania tamtejszego życia społecznego, nasiąknięcia cywilizacją"12.

\section{Polscy studenci w Innsbrucku po drugiej wojnie światowej}

Wraz z objęciem władzy w Polsce w 1944 r. przez komunistów wyjazdy na studia teologiczne zagranicą stały się niemożliwe. Kościół był wtedy na różne sposoby prześladowany. Celem polityki antykościelnej było zniszczenie jego struktur organizacyjnych, a wraz z nimi całego dorobku intelektualnego polskiego katolicyzmu. Będąc niekwestionowaną potęgą w wymiarze społecznym, Kościół dla reżimu stał się wrogiem numer jeden. Z drugiej strony właśnie ta jego siła sprawiała, że państwo musiało się z Kościołem bardziej liczyć niż z innymi ogniskami opozycyjnymi w kraju.

Dopiero po krwawych wydarzeniach na Wybrzeżu w grudniu 1970 r. i dojściu do władzy Edwarda Gierka ${ }^{13}$, w 1971 r. otworzyły się możliwości wyjazdu za granicę także przed duchownymi katolickimi. Temu zawdzięczaliśmy - ja i mój kolega seminaryjny Józef Mościbroda - nasz wyjazd do Innsbrucka na dalsze studia teologiczne, mając za sobą już trzy lata studiów w Wyższym Seminarium Duchownym w Lublinie, które było (i jest) częścią Wydziału Teologii Katolickiego Uniwersytetu Lubelskiego $^{14}$.

W Innsbrucku byliśmy pierwszymi polskimi studentami teologii; kto wie, czy nie pierwszymi w ogóle, którym umożliwiono kontynuowanie

12 B. Prus, Kroniki (1901-1910), wybór i red. S. Fita, t. II, Warszawa 1987, s. 142.

${ }^{13}$ Edward Gierek od 20 grudnia 1970 r. do 6 września 1980 r. był I sekretarzem Komitetu Centralnego Polskiej Zjednoczonej Partii Robotniczej. Strajki w sierpniu 1980 r. i powstanie Niezależnych Samorządnych Związków Zawodowych "Solidarność" zwiastowały całkowite załamanie się komunistycznego systemu w Polsce. Wybór w 1978 r. kard. Karola Wojtyły na papieża ostatecznie pasował Kościół w Polsce na Kościół triumfujący. Wizyta papieża Jana Pawła II w ojczyźnie w czerwcu 1979 r. przyczyniła się do tego jeszcze bardziej.

${ }_{14}$ Ta część tekstu oparta jest $\mathrm{w}$ dużej mierze na własnych wspomnieniach autora wzbogaconych aktualiami śledzonymi już z Polski, stąd użycie pierwszej osoby ma swoje uzasadnienie. Autorowi jest bowiem trudno wyizolować własną obecność w Innsbrucku w omawianym okresie. 
studiów teologii poza Polską. W mieście nad Innem zastaliśmy jedynie ks. Jerzego Wójcika z diecezji gdańskiej, który przybył do Austrii kilka lat wcześniej, w 1967 r., już jako kapłan. W Innsbrucku kontynuował studia doktoranckie z teologii moralnej ${ }^{15}$. Nasze przybycie do Collegium Canisianum wywołało pewną sensację. Oto z kraju zza żelaznej kurtyny, wyraźnie zależnego od Związku Sowieckiego i rządzonego przez komunistów, przyjechali alumni na dalsze studia teologiczne, do tego na wydziale prowadzonym przez jezuitów. Troskliwie się nami zajęli Ojcowie jezuici, zwłaszcza ówczesny regens Canisianum ks. Robert Miribung TJ.

W gronie studentów poznaliśmy jednego Czecha i kilku Słowaków - wszyscy pochodzili z nielegalnej emigracji. Więcej natomiast było Chorwatów i Słoweńców, obywateli ówczesnej Jugosławii, która nie weszła do bloku sowieckiego, dzięki czemu kontakty Kościoła z zagranicą nie były $\mathrm{w}$ takim stopniu utrudniane jak $\mathrm{w}$ krajach należących do obozu demokracji ludowej.

Rok po nas przybyli do Innsbrucka następni polscy studenci: z Lublina - Józef Niewiadomski i Jan Kusyk, a z Pelplina - Andrzej Krzyżan ${ }^{16}$ i Romuald Kobierowski. W 1973 r. grupa polska w Canisianum powiększyła się o dwóch kolejnych alumnów z seminarium pelplińskiego - Stanisława Majewskiego ${ }^{17}$ i Henryka Wryczę ${ }^{18}$. Rok później przyjechali dwaj księża z ówczesnej diecezji gorzowskiej-Kazimierz Walkowiak i Andrzej Gliński.

Dzięki solidnemu przygotowaniu filozoficznemu i teologicznemu wyniesionemu z kraju, grupa polskich studentów osiągała w Innsbrucku dobre postępy. Oczywiście trzeba było najpierw przezwyciężyć trudności językowe, co jednak nie stwarzało nam większych problemów. Z pozostałą grupą słowiańską tworzyliśmy w międzynarodowym środowisku Collegium Canisianum Słowiański Landsmannschaff ${ }^{19}$, k kórym próbowaliśmy,

${ }^{15}$ Ks. J. Wójcik był przez wiele lat duszpasterzem sióstr zakonnych w miasteczku Hall in Tirol k. Innsbrucka. Zmarł wskutek nieszczęśliwego wypadku drogowego 13 XI 2000 r. Pochowany jest na cmentarzu zakonnym w Hall in Tirol.

16 Ks. prałat mgr Andrzej Krzyżan jest kapłanem diecezji innsbruckiej. Obecnie (2013 r.) kieruje duszpasterstwem służby zdrowia diecezji Innsbruck.

17 Ks. mgr Stanisław Majewski jest kapłanem diecezji innsbruckiej. Obecnie (2013 r.) jest proboszczem w Vomp.

${ }_{18}$ Henryk Wrycza jest magistrem teologii i filozofii. Pracuje jako profesor historii i informatyki w szkolnictwie średnim w Hallein k. Salzburga.

19 Chociaż Landsmannschafty były stowarzyszeniami dobrowolnymi, nie obowiązującymi studentów, od początku swej działalności dążyły do włączenia w swe szeregi jak największej liczby młodzieży studenckiej. Chciały, i często potrafiły, nadać ton życiu studenckiemu. O działalności poszczególnych Landsmannschaftów w Collegium Canisianum zob. Das Canis und seine Canisianer, „Korrespondenzblatt des Canisianums” 1990, z. 1, s. 34-36; N. Wandinger, Die deutsche Landsmannschaft im Canisianum, ibidem (1991/92), 
zwłaszcza w początkowym okresie, porozumiewać się każdy w swoim ojczystym języku. Ponieważ zdarzało się przy tym dużo zabawnych nieporozumień, zazwyczaj przechodziliśmy na język „urzędowy” - niemiecki ${ }^{20}$.

Sympatia międzynarodowej grupy studenckiej w Innsbrucku towarzyszyła nam stale. Na pewno korzystaliśmy wiele z prestiżu Kościoła polskiego, jakim cieszył się wówczas na Zachodzie. Większość studiujących wiedziała coś o roli Częstochowy w dziejach Polski. Prawie każdy student, niezależnie z której półkuli, z szacunkiem wymawiał nazwisko prymasa Stefana Wyszyńskiego ${ }^{21}$.

Polskie władze konsularne w Wiedniu nie ułatwiały nam pobytu na studiach. Trudno było uzyskać przedłużenie ważności paszportu. W ciągu roku trzeba było czasami odbywać w tym celu nawet kilka kosztownych wyjazdów do Wiednia. Problemy z przedłużeniem paszportu łagodniały wyraźnie w przypadku domniemania chęci pozostania zagranicą. Z uwagi na częste próby infiltracji agend polonijnych w Austrii przez władze PRL 22 alumni studiujący w Innsbrucku unikali kontaktów z mieszkającymi w Austrii rodakami, aby mimo woli nie stać się narzędziem w ręku służb zagranicznych PRL ${ }^{23}$.

Studenci z całego świata mieszkający w Canisianum i studiujący na wydziale teologicznym [...] reprezentowali różne kultury i różne koloryty religijne - wspominał po latach ks. Józef Niewiadomski. - Łączyło nas jednak głębokie przekonanie religijne, że katolicyzm spełnia fundamentalną rolę w kontekście kształtowania kultury ogól-

z. 1, s. 40. O znaczeniu Landsmannschaftów na tle historii związków młodzieży w ogóle świetne studium dał A. Kamiński. Zob. tenże, Prehistoria polskich związków młodzieży, Warszawa 1959, s. 53-58.

${ }^{20}$ Podobnie opisuje swoje spotkania z przedstawicielami zwłaszcza Czechów i Słowaków w przededniu pierwszej wojny światowej Stanisław Grabski. Zob. tenże, Pamiętniki, do druku przygotował i wstępem opatrzył W. Stankiewicz, Warszawa 1989, s. 29.

${ }^{21}$ Takie same spostrzeżenia zebrał na przełomie 1995/96 r. ówczesny wikariusz generalny diecezji lubelskiej ks. Czesław Szczęsny w czasie swojej podróży po Erytrei. Zob. tenże, Kościół katolicki wspiera budowę niepodległego państwa Erytrea, „Pro Patria. Pismo Ziemi Chełmskiej" 1996, nr 4, s. 6.

22 O działalności niektórych organizacji polonijnych w Austrii por.: W. Kucharski, Związek Polaków w Austrii - ZPA (1945-1991), „Przegląd Polonijny” 1993, z. 2, s. 102 nn.; zob. Zwiazek Polaków w Austrii "Strzecha" (1894-1994), Lublin 1996.

${ }^{23}$ "Kościót $w$ Polsce był w czasach PRL-u jedynym poważnym organizmem nieupaństwowionym, niezasymilowanym przez ów system rzadzenia, który miał naturalna i niepohamowana dą̇ność do upaństwowienia wszystkiego - nie tylko środków wytwarzania, ale także ludzi, myśli, słów i wszelkich form komunikacji społecznej. Cały ten system chylił się ku upadkowi i prezentowat ideowa nędzę, działając tylko zakazem, zastraszeniem, nieprzerwanie usitując niszczyć wszystko, co w życiu narodu $i \dot{z} y c i u$ jednostek nie znalazło się pod jego wptywem. Wszystkie zachowania, uczucia i myśli, które uniknęty upaństwowienia stawały się czynnościami politycznymi, bez względu na ich intencje". J.A. Kabata, Panorama emigracyjnych wydawnictw katolickich w XX wieku, „Przegląd Polonijny” 1996, z. 1, s. 101. 
noświatowej. Canisianum było mikrokosmosem świata współczesnego oglądanego przez pryzmat katolicki ${ }^{24}$.

Z tej dziewięcioosobowej grupy pierwszych alumnów wysłanych na dalsze do Innsbrucka Polski w 1978 r. wrócił tylko jeden. Byłem to ja. Jan Kusyk zmarł w Innsbrucku 15 sierpnia 1973 r. wskutek nieszczęśliwego wypadku przy pracy ${ }^{25}$. Trzech studentów nie przyjęło święceń kapłańskich. Po ukończeniu teologii i innych studiów uzupełniających podejmowali przeważnie obowiązki katechetów w szkolnictwie różnych stopni bądź uczyli innych przedmiotów. Pozostali nadal pracują w duszpasterstwie.

Dwaj księża Józef Niewiadomski i ja, podjęli pracę naukową. O karierze naukowej ks. Niewiadomskiego warto napisać szerzej.

Był on najpierw asystentem na Wydziale Teologii w Innsbrucku, a w latach 1991-1996 profesorem Papieskiego Wydziału Teologicznego w Linzu. Przez cztery lata prowadził wykłady na Uniwersytecie w Salzburgu. Od 1996 r. jest profesorem zwyczajnym teologii dogmatycznej Uniwersytetu Leopolda-Franciszka w Innsbrucku. W tym samym roku został kierownikiem I Katedry Teologii Dogmatycznej, a więc następcą - choć nie bezpośrednim - o. Karla Rahnera, wybitnego jezuity. W latach 2004-2013 pełnił funkcje dziekana Wydziału Teologii na tej uczelni. W roku 2001 i 2004 wykładał jako visiting professor na Uniwersytecie w Jerozolimie oraz we Fryburgu Bryzgowijskim. W marcu 2000 r. został członkiem Europejskiej Akademii Nauki i Sztuki z siedzibą w Wiedniu.

Jest autorem (lub współautorem) kilkunastu cenionych książek, m.in. Eindeutige Antworten? (Thaur 1989), Den Frommen ein Skandal (Regensburg 1991), Vom Fluch und Segen der Sündenböcke (Thaur 1995), Faszinierendes Geheimnis. Neue Zugänge zur Eucharistie in Familie, Schule und Gemeinde (Innsbruck-Wien-Mainz 1999), Herbergsuche. Auf dem Weg zu einer christlichen Identität in der modernen Kultur (Münster-Hamburg-London 1999), Dramatische Theologie im Gespräch (Münster 2003), Religion erzeugt Gewalt - Einspruch. Innsbrucker Forschungsprojekt Religion - Gewalt - Kommunikation - Weltordnung (Münster 2003), Die theologische Hintertreppe. Die großen Denker der Christenheit (München 2005), Opfer - Helden - Märtyrer. Das Martyrium als religionspolitologische Herausforderung (Innsbruck-Wien 2011). Opublikował ponad 500 artykułów naukowych i popularnonaukowych. Wypromował 23 doktorów i około 100 magistrów.

24 J. Niewiadomski, Fascynujacy czas dramatycznych przełomów, w: Polacy na uniwersytecie w Innsbrucku, red. E. Walewander, Lublin 2001, s. 81-82.

${ }_{25}$ Pochowany w rodzinnej parafii w Michowie (dekanat lubartowski). Więcej na ten temat: Cz. S. Bartnik, Śmierć kleryka, w: Krzak Gorejacy. Homilie, kazania, przemówienia, Lublin 1991, s. 169-173. 
Swej aktywności nie ogranicza tylko do sfery naukowej. Gorliwie pracuje też w duszpasterstwie. W sierpniu 2001 r. przejął odpowiedzialność za duszpasterstwo środowisk twórczych w diecezji innsbruckiej. W każdą niedzielę odprawia mszę św. akademicką w kościele uniwersyteckim w Innsbrucku. Znany jest również z działalności publicystycznej, głównie z wielu dyskusji publicznych oraz z wygłaszania referatów popularnonaukowych. Wypowiada się w radiu i telewizji nie tylko krajów obszaru języka niemieckiego. Gościł z wykładami w Polsce, m.in. w Krakowie (1999) w Tarnowie (2009) i w Lublinie na KUL (2002). W swych wystąpieniach nie unika tematów bieżących, kontrowersyjnych. Swoją odwagą i jednoznacznością poglądów zdobył powszechne uznanie i szacunek.

Zawsze podkreśla, że jest Polakiem. Nie pozwala nawet zniemczyć swojego imienia na Josef. Wymaga, aby pisano je w polskim brzmieniu. Jego ogromny dorobek, zawsze łączony z polskością ma duże znaczenie wobec obserwowanej obecnie fali antypolonizmu, przejawiającego się w różnych formach. Walczy z nim swoją pracą kapłańską oraz osobistym świadectwem.

Zabiera też głos w publikacjach krajowych. Dużo pisał na przykład o austriackich doświadczeniach $\mathrm{w}$ konfrontacji ze współczesnym liberalizmem. Tą drogą ostrzega przed powielaniem błędów społeczeństw zachodnich w naszych zmaganiach o ratowanie tego, co istotne w Kościele w ogóle, a zwłaszcza w Kościele polskim. Nie utracił nigdy łączności z krajem. Pomaga wszelkimi sposobami Polakom, którzy szukają w nim oparcia. Stara się upowszechniać dorobek polskiej nauki teologicznej. Osiągnięcia polskich teologów za pośrednictwem jego omówień i recenzji trafiają niejednokrotnie na Zachód.

W październiku 2002 r. ks. prof. zw. Józef Niewiadomski za swą pracę naukową na Uniwersytecie Leopolda-Franciszka w Innsbrucku, podnoszącą prestiż nauki polskiej, został wyróżniony przez Katolicki Uniwersytet Lubelski Nagrodą Naukową im. Ireny i Franciszka Skowyrów. Zadanie teologii opartej na judeochrześcijańskim Objawieniu i Tradycji Kościoła rozumie przede wszystkim jako wejście $\mathrm{w}$ dialog z zsekularyzowaną kulturą w ramach panujących w niej standardów myślowych, po to, by korzystając z nich, dokonać pozytywnych z punktu widzenia chrześcijańskiego zmian w mentalności współczesnego człowieka ${ }^{26}$.

${ }^{26}$ Por. A. Romejko, Polski duchowny „ambasadorem sprawy polskiej zagranica”. Wspomnienia z pracy duszpasterskiej i naukowej w Innsbrucku (1999-2004), "Miesięcznik Archidiecezji Gdańskiej" 2005, nr 5, s. 739-747; tenże, Ks. prof. Józef Niewiadomski - wspóttwórca "teologii dramatycznej" na uniwersytecie w Innsbrucku, „Rocznik Polonii” 2005, nr 1, s. 83-87; E. Walewander Ksiądz profesor Józef Niewiadomski, dziekan Wydziatu Teologii w Innsbrucku kanonikiem lubelskim, „Wiadomości Archidiecezji Lubelskiej. Memoranda” 2010, nr 4, s. 553-555; toż 
W tym miejscu wypada powiedzieć coś o moim dorobku naukowym. Pracę naukowo-dydaktyczną na KUL rozpocząłem 1 października 1980 r., prowadząc wykłady z historii Kościoła na Wydziale Teologii. W latach 1983-1985 pracowałem jako starszy asystent w międzywydziałowym Instytucie Badań nad Polonią i Duszpasterstwem Polonijnym KUL (od 1985 do 1995 r. jako adiunkt). Od września 1990 do marca 2005 r. byłem dyrektorem tego instytutu. Od 1997 r. jestem kierownikiem Katedry Pedagogiki Porównawczej w Instytucie Pedagogiki na Wydziale Nauk Społecznych KUL. W tym też roku zostałem mianowany profesorem KUL. W 2009 r. otrzymałem tytuł naukowy profesora nauk humanistycznych. Dwa lata później zostałem profesorem zwyczajnym.

Prowadziłem liczne wykłady i odczyty w środowiskach naukowych Austrii i Niemiec. W latach 1993-2002 byłem prezesem Oddziału Lubelskiego Stowarzyszenia „Wspólnota Polska”.

Główne kierunki moich badań naukowych to pedagogika chrześcijańska i problematyka polonijna. Interesuję się również duchowością chrześcijańską i historią Kościoła. Opublikowałem 24 własne książki, a pod moją redakcją i jako współautor - 39 pozycji książkowych. Ogółem wydałem 803 prace naukowe i popularnonaukowe. Wypromowałem dziewięciu doktorów i 176 magistrów. Pod moim kierunkiem napisano 31 prac licencjackich. Stworzyłem i przez kilkanaście lat redagowałem serię wydawniczą Biblioteka Polonii. Od 1997 r. wydaję Bibliotekę Pedagogiczną (seria A. Studia i seria B. Materiały i Dokumenty). Dotychczas ukazały się w niej 34 tomy (jeden w języku angielskim). W latach 1990-2005 byłem redaktorem naczelnym „Studiów Polonijnych”. Przez kilka lat (1997-2002) pełniłem funkcję redaktora naczelnego „Roczników Nauk Społecznych” zeszyt „Pedagogika”. Od 1995 r. jestem prezesem ogólnopolskiego Towarzystwa Naukowego Polska-Wschód.

W okresie późniejszym do Innsbrucka kierowano z Polski przede wszystkim księży, którzy zasadniczą formację zdobyli już w kraju.

W 1978 r. z diecezji lubelskiej do Innsbrucka wysłano dwóch kapłanów: ks. Wiesława Bielaszewskiego i ks. Mieczysława Turka.

Ksiądz B i e l a s z e w s k i bezpośrednio po zakończeniu studiów filozoficznych w Innsbrucku w 1987 r. został duszpasterzem Polaków w Neu Wulmstorf koło Hamburga. Pracował tam 25 lat, aż do przejścia na emeryturę w 2012 r. Jako emeryt wrócił do Polski. Mieszka w Warszawie.

Ksiądz T u r e k studiował w Innsbrucku do 1979 r. Obronił tam doktorat, po czym powrócił do diecezji lubelskiej. Pracował w duszpasterstwie. W 1982 r. biskup lubelski Bolesław Pylak skierował go do pracy

(wersja poszerzona), „Lublin. Kultura i Społeczeństwo” 2010, nr 5, s. 88-89. 
duszpasterskiej w Bawarii. W 2009 r. ks. Turek został inkarnowany do archidiecezji bamberskiej, gdzie pełnił obowiązki proboszcza, m.in. w parafii Scheßlitz.

W 2012 r. arcybiskup lubelski Stanisław Budzik wysłał na dalsze studia teologiczne do Innsbrucka ks. Łukasza M u d r a k a.

W Innsbrucku studia specjalistyczne odbyło kilku księży z diecezji tarnowskiej.

Ksiądz Zygmunt Z i m o w s k i otrzymał w 1982 r. w Innsbrucku stopień doktora w zakresie teologii dogmatycznej. W latach 2002-2009 pełnił obowiązki biskupa radomskiego. Od 2008 do 2009 r. był delegatem Konferencji Episkopatu Polski ds. Duszpasterstwa Emigracji. W 2009 r. papież Benedykt XVI mianował go przewodniczącym Papieskiej Rady ds. Duszpasterstwa Służby Zdrowia. Równocześnie wyniósł go do godności arcybiskupiej. Ksiądz Zimowski jest autorem ponad 120 publikacji, m.in. Karolina Kózka: il coraggio del innocenta (Roma 1987); Modlitwa droga nawrócenia i służby w ujęciu Katechizmu Kościoła Katolickiego (Tarnów 1998); Jan Pawet II: encyklopedia pontyfikatu 1978-2005 (Radom 2005).

W 1982 r. w Innsbrucku studia specjalistyczne w zakresie dogmatyki rozpoczął ks. Stanisław B u d z i k. Uwieńczył je uzyskaniem w 1988 r. stopnia doktora. Habilitował się w 1997 r. na kierunku teologia na Wydziale Teologicznym Papieskiej Akademii Teologicznej w Krakowie na podstawie rozprawy Dramat odkupienia. Kategorie dramatyczne w teologii na przykładzie R. Girarda, H.U. von Balthazara i R. Schwagera. Wkrótce został profesorem nadzwyczajnym. Pełnił obowiązki rektora Wyższego Seminarium Duchownego w Tarnowie, a od 2004 r. biskupa pomocniczego tarnowskiego. Od 2011 r. sprawuje funkcję arcybiskupa lubelskiego i Wielkiego Kanclerza KUL. Jest autorem ponad 20 publikacji zwartych (m.in. Doctor pacis. Theologie des Friedens bei Augustinus (Innsbruck-Wien 1988); Maryja w tajemnicy Chrystusa i Kościoła (Tarnów 1997); Jesteśmy Kościołem Chrystusa (Tarnów 1994); Moc i piękno wiary (red.) (Tarnów 1995); Dramat odkupienia. Kategorie dramatyczne w teologii na przyktadzie R. Girarda, H.U. von Balthasara i R. Schwagera (Tarnów 1997); Czy wolno mieć nadzieję, że wszyscy będa zbawieni? (Tarnów 1998); Fides querens intellectum (Tarnów 2006). Ogłosił około 150 artykułów naukowych i popularnonaukowym oraz ponad 100 publikacji o charakterze duszpasterskim.

Od 1992 r. przez kilka lat studiował w Innsbrucku ks. Robert B i e 1, który obronił tam doktorat z teologi pastoralnej. W 2013 r. uzyskał na KUL stopień doktora habilitowanego. Jest autorem bądź redaktorem kilkunastu książek, m.in. Lebens- und Todeszeichen der Kirche in Polen nach der Wende, (Innsbruck-Tarnów 2001).

W Innsbrucku od 1988 r. studiował ks. Michał D r o ż d ż. Doktorat obronił w 2003 r. Cztery lata później habilitował się w Różomberku 
na Słowacji. Jest autorem kilkunastu książek, wśród nich m.in. Człowiek w świecie mediów (Tarnów 2012) i Dobro w mediach: z cienia do światła (Tarnów 2012).

W latach 1993-1997 studiował w Innsbrucku ks. Janusz K a l e t a, który zdobył tu w 1997 r. doktorat z teologii moralnej. W 1999 r. wyjechał do pracy duszpasterskiej w Kazachstanie. Wkrótce Jan Paweł II mianował go administratorem apostolskim Atyrau. Konsekrecję biskupią ks. Kaleta otrzymał w 2006 r. w Watykanie. Papież Benedykt XVI mianował go biskupem Karagandy.

W Innsbrucku studiowało także pięciu innych księży diecezji tarnowskiej: Edward F a j t, Wiesław P i o t r o w s k i, dr Mieczysław P y r e k, Marcin K o k o s z k a oraz dr Roman S t a f i n, który od 1997 r. pracuje w niemieckiej diecezji Hildesheim.

$\mathrm{Na}$ uniwersytecie Leopolda-Franciszka studiował ks. dr Antoni Władysław S o w a, dawny rektor Wyższego Seminarium Duchownego w Kielcach. W latach 1984-1989 odbył tu studia ks. Mirosław K r z y w a k z diecezji łomżyńskiej, natomiast od 2008-2009 ks. Rafał M o s i o r, kapłan diecezji rzeszowskiej.

W latach 1999-2004 w Innsbrucku był na studiach specjalistycznych kapłan diecezji gdańskiej ks. Adam R o m e j k o, który wcześniej doktoryzował się na Uniwersytecie Gdańskim. Drugi doktorat, z teologii dogmatycznej, obronił w 2004 r. w Innsbrucku. Opublikował wspomnienia z pracy duszpasterskiej i naukowej w Innsbrucku, w których podkreślił m.in., że Polaków "chwalono za poprawna znajomość języka niemieckiego"27.

Po 1989 r. w Innsbrucku studiowali również d u chowni jezu i cc y. Udało się ustalić sześć nazwisk: Grzegorz Dobro c zyń s ki, Karol Tomasz Giedrojć, Bernard Gonska, Stanisław Łucarz, Wit Pasierbeki Krzysztof Skorulski ${ }^{28}$.

\section{Duszpasterstwo polskie w Innsbrucku}

Polscy kapłani studiujący i pracujący w Innsbrucku angażowali się w duszpasterstwo Polaków mieszkających w tym mieście i w różnych regionach Tyrolu. „To dzięki ich zaangażowaniu - napisał Bogdan Wasilewski, prezes Związku Polaków w Tyrolu „Strzecha” - „od końca lat 80. najpierw w kościele Allerheiligen, a następnie w kościele Jezuitów w Innsbrucku

27 Romejko, Polski duchowny „ambasadorem sprawy polskiej zagranica”, s. 744.

28 K.T. Giedrojć, Duszpasterstwo polskie w Innsbrucku dzisiaj, w: Polacy na uniwersytecie w Innsbrucku, s. 85. 
w co drugą niedzielę odbywają się msze święte w języku polskim"29. Ankieta dotycząca nastawienia do religii i ogólnego samopoczucia Polaków żyjących w Innsbrucku i całym Tyrolu, przeprowadzona w 2000 r., wskazała na bardzo pozytywny odbiór pracy duszpasterskiej i roli Kościoła katolickiego w życiu tamtejszej Polonii, bez względu na wykształcenie i rodzaj wykonywanego zawodu ${ }^{30}$.

\title{
Zakończenie
}

Kierowanie studentów teologii zagranicę, gdzie kończyli oni studia seminaryjne, a nawet specjalistyczne - uniwersyteckie, nie było w Polsce niczym nowym. Świadczyło o trwałej więzi Kościoła polskiego ze strukturami kościelnymi Zachodniej Europy, a także z kulturą zachodnią. Studia podejmowane przez polskich studentów teologii za czasów Polski Ludowej, w okresie szczególnie niekorzystnym dla takich kontaktów, miały jednak specjalne znaczenie; dowodziły bowiem, że Kościół nie zamierzał podporządkować się gettyzacji narzucanej narodowi przez komunizm. Dlatego możliwy też był dialog z Zachodem na płaszczyźnie kościelnej, wyprzedzający w czasie i materii dialogowej to, czym dzisiaj szczycą się niektóre „elity” polskie. Należy ten fakt na tym miejscu przypomnieć, gdyż środowiska przywłaszczające sobie teraz monopol na dialog zwykle zapominaja, kto, kiedy i gdzie był jego pionierem.

\section{Zusammenfassung}

\author{
POLNISCHE THEOLOGIESTUDENTEN \\ IN INNSBRUCK NACH DEM 2. WELTKRIEG
}

Eines der wichtigsten ausländischen Zentren war Innsbruck. Die nach solidem Wissen Suchenden zog das hier seit 1561 bestehende Jesuitenkolleg an, seit 1669 eine Universität. In der Zeit der Polnischen Teilungen wurde Innsbruck vor allem von Geistlichen aus dem österreichischen Teilungsgebiet gewählt. In der Zwischenkriegszeit studierten hier Priester aus fast allen Diözesen Polens.

Nach der Machtübernahme der Kommunisten in Polen im Jahre 1944 war es für Theologiestudenten nicht mehr möglich, im Ausland zu studieren. Erst als Edward Gierek 1971 an die Macht kam, eröffneten sich auch für katholische Geistliche wieder Möglichkeiten, ins Ausland zu reisen. Dem verdankten wir - ich und mein Kollege Józef Mościbroda - un-

29 B. Wasilewski, Nasz dom w Tyrolu, „Nowy Dziennik” z 27 VII 2003, s. 19.

${ }^{30}$ K.T. Giedrojć, Duszpasterstwo polskie w Innsbrucku dzisiaj, w: Polacy na uniwersytecie w Innsbrucku, s. 86. 
sere Reise nach Innsbruck zu weiteren Studien. Ein Jahr nach uns kamen dann auch schon die nächsten Studenten aus Lublin - Józef Niewiadomski und Jan Kusyk, und aus Pelplin - Andrzej Krzyżan und Romuald Kobierowski. 1973 vergrößerte sich die polnische Gruppe in Innsbruck um weitere Studenten aus Pelplin - Stanisław Majewski und Henryk Wrycza. Ein Jahr später folgten zwei Priester aus der Diözese Gorzów - Kazimierz Walkowiak und Andrzej Gliński.

In späterer Zeit wurden aus Polen vor allem Priester nach Innsbruck geschickt - 1978 waren dies aus der Diözese Lublin Wiesław Bielaszewski und Mieczysław Turek. Zu Spezialstudien kamen mehrere Priester aus der Diözese Tarnów nach Innsbruck: Zygmunt Zimowski, Stanisław Budzik, Michał Drożdż, Janusz Kaleta, Edward Fajt, Wiesław Piotrowski, Mieczysław Pyrek, Marcin Kokoszka und Roman Stafin. Hier studierte auch ein Priester aus der Diözese Gdańsk - Adam Romejko.

Dass Theologiestudenten ins Ausland geschickt wurden, war in Polen nichts Neues. Dies zeugte von der dauernden Verbindung der polnischen Kirche mit den kirchlichen Strukturen Westeuropas sowie mit der westlichen Kultur überhaupt. Das Auslandsstudium polnischer Theologiestudenten in der Zeit der Polnischen Volksrepublik, in einer für solche Kontakte besonders ungünstigen Zeit, war ein Beweis dafür, dass die Kirche keineswegs beabsichtigte, sich einer der Nation vom Kommunismus aufgezwungenen "Ghettoisierung" unterzuordnen. 